\title{
ESTIMATION OF EMISSIONS BY ROAD VEHICLES IN THE METROPOLITAN REGION OF SALVADOR, BRAZIL
}

\author{
KATTY SANTOS DA SILVA MARQUES, ANDERSON DA SILVA PALMEIRA, \\ DAVIDSON MARTINS MOREIRA \& ERICK GIOVANI SPERANDIO NASCIMENTO \\ Centro Universitário SENAI CIMATEC, Brazil
}

\begin{abstract}
This study focuses on atmospheric emissions from road vehicles in the Metropolitan Region of Salvador (RMS), northeaster Brazil. To investigate and analyse the contributions to air pollution, the methodology proposed and developed by the Ministry of the Environment (MMA) is used in the 1st National Inventory of Road Vehicle Emissions in 2011, the application of which has been published annually by the State Environmental Company of São Paulo (CETESB), from the 1st Vehicle Emissions Report, of which electric, hybrid and CNG vehicles are not considered. Usually, in the preparation of inventories, the emission rates are estimated according to the circulating fleet categorized by tonnage (light/heavy and passenger/cargo), type of fuel used, intensity of use and emission factors. Emissions are due to exhaust, fuel evaporation rate and tire, brakes, and track wear. Although, the emission inventories present uncertainties associated with the calculation of emissions according to the characteristics of the fuel, the circulating fleet and the technology on board, these inventories are powerful tools in this type of research. In this sense, the objective of this work was to elaborate an inventory of emissions by road vehicles in the RMS, referring to the period from 2013 to 2017 , to subsidize the management of air quality in the RMS. The results show that RMS owns $36.48 \%$ of the circulating fleet in the State of Bahia, comprising approximately $65 \%$ of automobiles and $7.0 \%$ of heavy vehicles (trucks and buses) and heavy vehicles emit the highest levels of $\mathrm{NO}_{\mathrm{x}}$ and PM, with approximately $84 \%$ and $70 \%$, respectively.

Keywords: metropolitan region of Salvador, road vehicles, $N O_{x}, M P$.
\end{abstract}

\section{INTRODUCTION}

The growing volume of motor vehicles circulating on the highways is a worrying trend in air quality management. This trend is evident in the fact that most vehicles that make up the circulating fleet have outdated technology and use fossil fuels, contributing significantly to air pollution.

As a result, there is an increase in atmospheric emissions, where some of the compounds emitted are carbon monoxide, nitrogen oxides, particulate matter, etc. The complex interactions of compounds of different nature associated with the microclimate potentiate the greenhouse effect, triggering effects such as acid rain, heat islands, thermal inversion, etc. According to the World Health Organization (WHO) in 2018 it was estimated that 7 million people die annually from air pollution [1].

The RMS is located between the Recôncavo of Bahia and the Northeast of Bahia (North Coast), being the eighth largest pole of national wealth, where the municipalities of Camaçari, Candeias, Dias d'Ávila, Itaparica, Lauro de Freitas, Madre de Deus are located, Mata de São João, Pojuca, Salvador, São Francisco do Conde, São Sebastião do Passé, Simões Filho and Vera Cruz, as shown in Fig. 1.

Fig. 1 represents the RMS as an urban-industrial region where 1,446,336 vehicles are located, that is, $36.48 \%$, of the State's fleet [2]. Since air pollution is an environmental, social, and economic challenge. Therefore, in this perspective, this work proposed to investigate road emissions in the RMS, and for this, an inventory of road atmospheric 


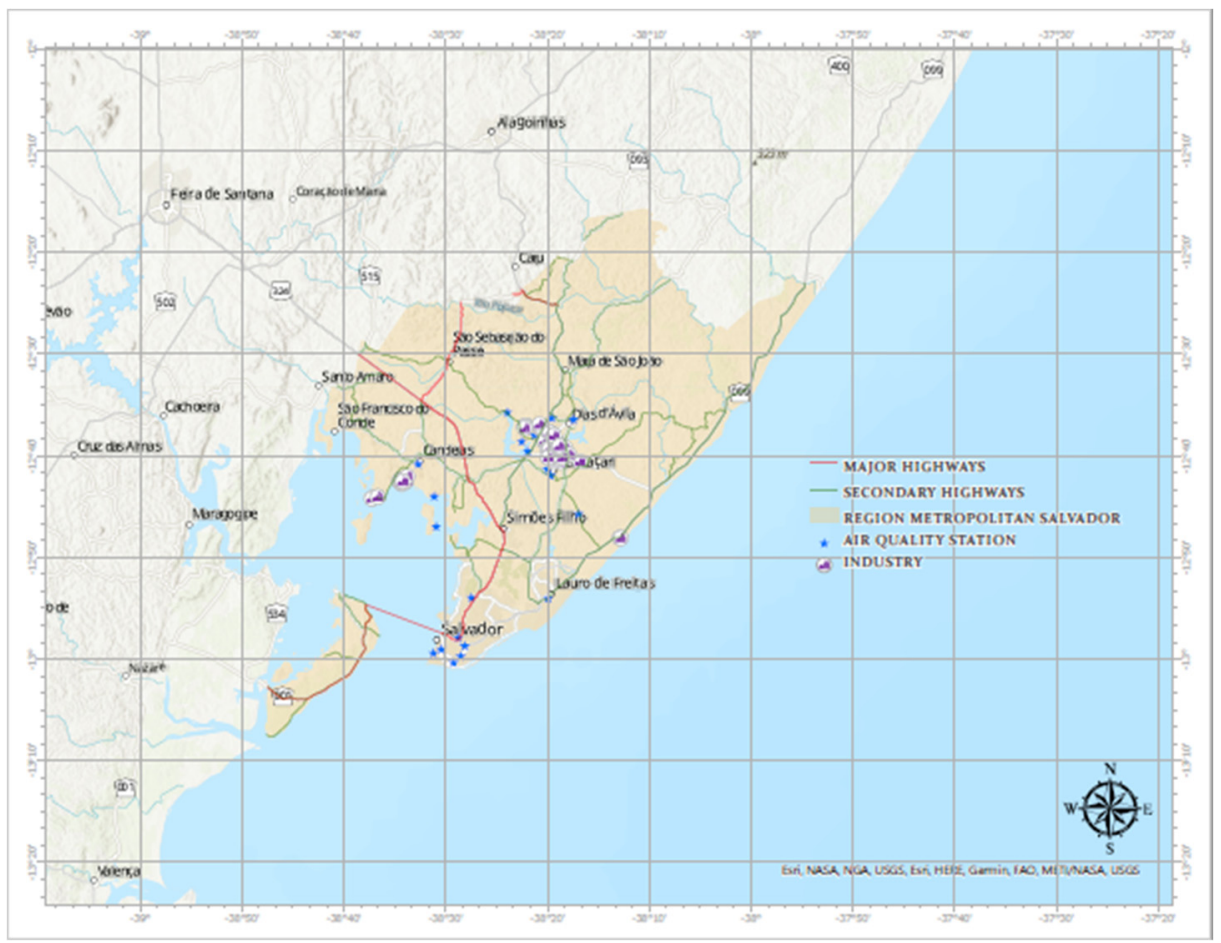

Figure 1: Geographic location of the study area containing the location of the main mobile, fixed sources, and air quality monitoring stations.

emissions was prepared, considering the period from 2013 to 2017, representing the state of the art in this sense.

\section{LITERATURE REVISION}

The emission inventories elaborate for road vehicles makes it possible to investigate the contribution of these sources. Analysing the RMS, authors such as Lyra [3] and De Aguiar Filho and de Albuquerque [4], developed studies in this direction.

In the study by Lyra [3], a survey of vehicle and industrial emissions and some one-off emissions aimed at generating necessary information to propose an integrated model of air quality management and found that despite industrial concentration vehicle emissions are on average $75 \%$ of all air emissions in the region.

In the study by De Aguiar Filho and de Albuquerque [4], they proposed to investigate the vehicle emissions where the emissions of carbon monoxide (CO), total hydrocarbons (THC), nitrogen oxides $\left(\mathrm{NO}_{\mathrm{x}}\right)$, sulfur oxides $\left(\mathrm{SO}_{\mathrm{x}}\right)$ and particulate matter $(\mathrm{PM})$ were estimated and the authors found high co emissions that are responsible for cardiovascular complications and changes in the nervous system, increased $\mathrm{NO}_{\mathrm{x}}$ emissions, and THC that contribute to the production of tropospheric ozone and the increase of pm emissions that the smaller the particle size are called inhalable particles $\left(\mathrm{PM}_{10}\right)$ and fine inhalable particles $\left(\mathrm{PM}_{2.5}\right)$ that penetrate deeply into the lungs and the cardiovascular system.

Even though rms has one of the largest air quality monitoring networks in Brazil, totalling 24 stations (10 stations in the city of Salvador and the other 14 in those installed in 
other cities), the region still lacks continuous studies in this sense, aiming at investigations using models of air quality enabling a more realistic scenario of air quality as has been done for other metropolitan regions [5].

The southeast region of Brazil concentrates the most developed metropolitan regions in the continuous elaboration of studies focused on air quality and dispersion of pollutants. In the greater São Paulo metropolitan Region (RMSP) [6], several studies have been carried out in this regard, among them the UEDA study, which investigated vehicle emissions in 2011 and found that $\mathrm{CO}, \mathrm{THC}$, and $\mathrm{NO}_{\mathrm{x}}$ emissions represent more than $75 \%$ of total emissions.

The Greater Vitória Metropolitan Region (RMGV) has developed in this direction and studies such as that by Loriato et al. [7] has been elaborated in the region where using the local inventory elaborated by the State Institute of the Environment (IEMA) for the year of 2010. From this, an atmospheric modelling was done realized an atmospheric modelling using the integration of models as the meteorological model Weather Research and Forecasting Model (WRF) [6], the model Sparse Matrix Operator Kernel Emissions (SMOKE) which processes the inventory to the required format in air quality models, and the Community Multiscale Air Quality Model (CMAQ) chemical air quality model that processes wrf and smoke information [6] and generates local chemical concentrations hourly [8].

Among the results obtained, the authors found that vehicle emissions contribute about $74.63 \%$ of $\mathrm{PM}_{10}, 73.42 \%$ of $\mathrm{PM}_{2.5}, 33.38 \% \mathrm{NO}_{\mathrm{x}}, 49.61 \%$ of $\mathrm{CO}$. Demonstrating the relevance of these studies as strategic tools for local air quality management [6], [9], [10].

\section{METHODOLOGY}

Emission inventories are relevant tools in studies focusing on air quality, being used as input data in air quality models. In general, based on these data, emissions are estimated in annual periods. The approach described consists in the elaboration of emission inventories with the objective of estimating atmospheric emissions from road vehicles and something of this type has not yet been done in the region.

In these quantifications, vehicles are considered by categories: automobiles, light commercial vehicles, trucks, buses, and motorcycles [11], [12]. According to the fuel consumed, vehicles are categorized into: vehicles powered by gasoline, ethanol, flex (fourstroke internal combustion engine that has the capacity to be refuelled and work with more than one type of fuel, mixed in the same tank and burned in the combustion chamber simultaneously) and diesel [11], [12]. Hybrid, electric and GNV vehicles are not analysed. And we consider that the emissions occurring by exhaustion (discharge pipe), evaporation (supply, braking, acceleration, deceleration, and rest) and by the friction between the tires, brakes, and tracks [11], [12].

Fig. 2 summarizes the methodology developed by the Ministry of the Environment for road vehicles in a summarized way, being the most widespread method today [12].

In Fig. 2, we see the input data highlighted in blue and the outputs that are obtained by applying the estimation equations to these data in red.

The circulating fleet $(F C)$ is a particularly important data for this type of evaluation, being obtained through the sales history of new vehicles, applying survival rates where the probability of scrapping of vehicles is considered according to the time of use of the vehicles (from the year of manufacture), see eqn (1):

$$
F c=V \cdot S
$$




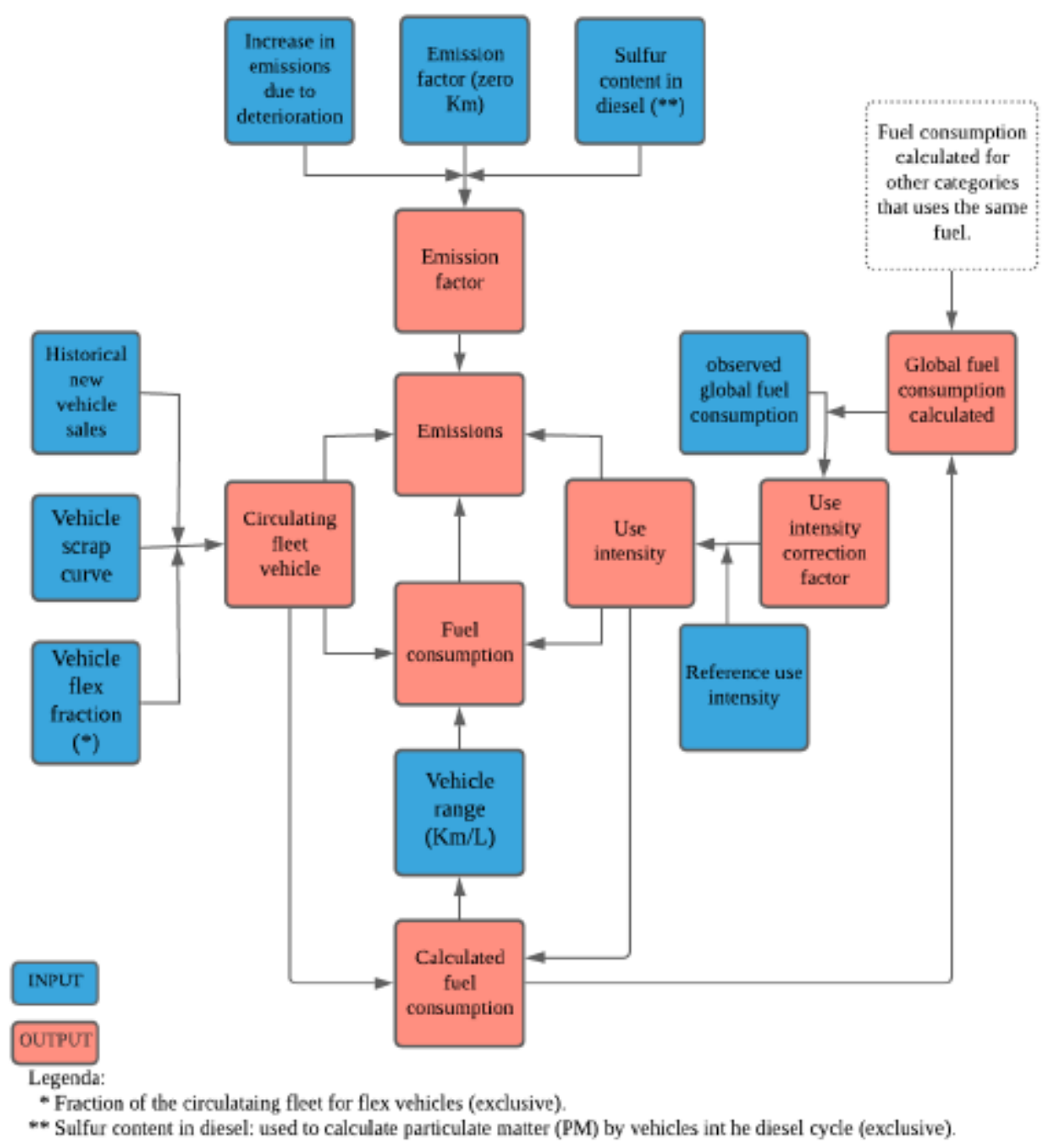

Figure 2: Summary of the steps of the inventory elaboration method.

where is the circulating vehicle fleet, $V$ is the number of vehicles that came into circulation and $S$ is the vehicle survival rate (or scrapping function of automotive vehicles) according (model-year) $\mathrm{k}$ in the (calendar-year) $\mathrm{i}$. To determine a function that better describes the scrapping process for light vehicles, three functions were tested: Logistics, Gompertz and Weibull, the latter being used in international literature. However, the Gompertz function was chosen [13], [14] for better adapting to the data under analysis [3]-[8], [10]. In Otto cycle engines, see eqn (2), and in diesel cycle engines and motorcycles, see eqn (3), the survival curves are obtained through a Gompertz function:

$$
S(t)=1-e^{-e(a+b . t)},
$$


where $S(t)$ is the survival rate, that is, the fraction of remaining vehicles not yet scrapped at age $t$, and $a$ and $b$ are variable parameters according to each type of vehicle.

$$
S(t)=\frac{1}{1+e^{a\left(t-t_{0}\right)}}+\frac{1}{1+e^{a\left(t+t_{0}\right)}},
$$

In eqn (3), " $a$ " and " $t_{0}$ " are variable parameters according to each type of vehicle. To estimate the fraction of flex-fuel vehicles, that is, those that use gasoline and alcohol as fuel, an analysis was made based on the price of these fuels where if on average the price of ethanol is less than $70 \%$ of the price of gasoline the owner supplies with ethanol and if the price of ethanol is greater than $70 \%$ of the price of gasoline, the owner supplies with gasoline. From this, a list of these prices was made [15] and it was observed that in the period evaluated for the region, the owners of flex vehicles supplied primarily with gasoline.

For the calculation of emissions, the circulating fleet is used $(F c)$, data on the intensity of use of each category and the emission factors, see Fig. 2. Intensity of use is the average distance travelled for each vehicle category in a unit of time (year). For Brazil, the average values estimated in the first national inventory for road vehicles are used [11], [12] and adjusts to the local reality, as eqn (4), adapting based on the fuel consumption of each vehicle category according to actual consumption, eqn (4) [11], [12]. This relation is given by:

$$
C e_{C, T, A}=\frac{\sum_{T=1}^{t} \sum_{A=1}^{a}\left(F c_{T, A} \cdot I u r_{T, A}\right)}{Q l_{T, A}},
$$

where $C e$ is the estimated total annual fuel consumption for the vehicle categories and their respective model-year; is the reference usage intensity for each vehicle category and their respective model year; is the range that represents the mileage travelled per litter of fuel consumed by each vehicle category and their respective model year; $T, C$, and $A$ are respectively the type of fuel, the category of vehicle and the model year.

From the estimated consumption $(\mathrm{Ce})$, the actual consumption $(\mathrm{Cr})$ and the intensity of reference use (Iur) the adjusted intensity of use is obtained (Iua) by vehicle category in their respective model-year as eqn (5):

$$
\operatorname{Iua}_{C, T, A}=\operatorname{Iur}_{T, A} \cdot \frac{C r}{C e_{C, T, A}},
$$

where, is the intensity of use adjusted for each vehicle category and their respective model year; $\mathrm{Cr}$ is the actual consumption of each type of fuel; $\mathrm{Ce}$ is the total annual consumption of a type of fuel estimated for all vehicle categories and their respective model year.

Emission factors are representative values that estimate the amount of a given pollutant released as a function of an activity associated with the release of that pollutant (see USEPA) [16]. In Brazil, there is still insufficient data on road vehicle emission factors under real conditions of use. With this, data referring to homologation tests for new vehicles are used and for this reason an increase in the rounded mileage was made to reduce the uncertainties associated with the maintenance conditions and the driving patterns of the vehicle. The increment values were determined for the pollutants $\mathrm{CO}, \mathrm{NO}_{\mathrm{x}}, \mathrm{NMHC}$ and 
RCHO and were added to the emission factors every $80,000 \mathrm{~km}$, except for vehicles of the diesel cycle and motorcycles due to the absence of this information.

Through the methodology adopted [11], [12] road vehicle emissions from exhaust, evaporation and wear of tires, brakes and tracks were estimated. Exhaust emissions refer to the operation of the vehicle's exhaust system and are estimated as eqn (6):

$$
E_{P, T, C}=\frac{F c_{T, C, A} \cdot I u a_{T, C, A} \cdot F e_{P, T, C, A}}{10^{6}},
$$

where $E$ is the emission rate (t/year); $\mathrm{Fe}$ is the emission factor expressed in terms of the mass of pollutant emitted per $\mathrm{km}$ travelled $(\mathrm{g} / \mathrm{km})$ and $P$ is the pollutant evaluated [11], [12]. Evaporative emissions from road vehicles can occur through three processes. Daytime emissions that refer to emissions by fuel evaporation as a function of local temperature, emissions from the engine cooling process after use and emissions from fuel loss while the vehicle is in motion. For all cases, specific temperature ranges are considered $\left(10^{\circ} \mathrm{C}\right.$ to $15^{\circ} \mathrm{C}, 10^{\circ} \mathrm{C}$ to $25^{\circ} \mathrm{C}$ and $20^{\circ} \mathrm{C}$ to $35^{\circ} \mathrm{C}$ ), to estimate the number of days in percentages, an analysis of the average daily temperatures of the season was made. conventional weather forecast in Salvador available at the National Meteorological Institute (INMET) and the same behaviour is considered for the entire region.

Daytime emissions were obtained from eqn (7):

$$
E_{N M H C_{d, T, C, A}}=\frac{F c_{T, C, A} \cdot e d_{T, C, A, F} \cdot D f}{10^{6}},
$$

where, $E_{N M H C d}$ is the NMHC emission rate by evaporation in the daytime phase (t/year); ed is the emission factor for NMHC evaporation in the daytime (g/day) given in terms of vehicle category, fuel type, year of manufacture and temperature range; $D f$ is the number of days to be considered for choosing the emission factor in each temperature range, and $d$ represents the evaporative emissions in the daytime phase [11], [12].

In relation to the emissions from the engine cooling process after use and the emissions from fuel loss with the vehicle in progress, the emission factors es and er are given in $\mathrm{g} / \mathrm{trip}$ so for these a conversion to $\mathrm{g} / \mathrm{km}$ was made by use of the average distance traveled per trip in individual transport in the RMS (km/trip). Emissions from the engine cooling process after use were obtained using eqn (8):

$$
E_{N M H C_{s, T, C, A}}=\frac{F c_{T, C, A} \cdot \operatorname{Iu}_{T, C, A} \cdot \frac{e s_{T, C, A, F}}{9,48} \cdot \operatorname{Df}(\%)}{10^{6}},
$$

where, $E_{N M H C S}$ is the NMHC emission rate in the engine cooling process after use (t/year); es is the emission factor for NMHC evaporation in the engine cooling process ( $\mathrm{g} /$ day) given in terms of vehicle category, fuel type, year of manufacture and temperature range [10], [11].

Emissions from fuel loss with the vehicle in progress were obtained using eqn (9):

$$
E_{N M H C_{r, T, C, A}}=\frac{F c_{T, C, A} \cdot \operatorname{Iu} a_{T, C, A} \cdot \frac{e r_{T, C, A, F}}{9,48} \cdot \operatorname{Df}(\%)}{10^{6}}
$$


where $E_{N M H C r}$ is the NMHC emission rate of the fuel loss with the vehicle in progress (t/year); er is the emission factor for NMHC evaporation in the engine cooling process (g/day) given in terms of vehicle category, fuel type, year of manufacture and temperature range.

Emissions due to wear of brakes, tires and tracks are generated from the wear of vehicle brakes as a function of use, friction between tires and tracks and the resuspension of material deposited on the roads. To estimate these emissions, emission factors were used based on the TIER 1 methodology [16], [17]. And they were obtained from eqn (10):

$$
E_{P, T}=\sum_{C=1}^{c} \sum_{A=1}^{a} \frac{\left(F c_{T, C, A} \cdot \operatorname{Iu}_{T, C, A}\right) \cdot F e_{P, T}}{10^{6}},
$$

where $E_{P, T}$ is the emission rate ( $\mathrm{t} /$ year); $P$ is the pollutant evaluated.

\section{RESULTS AND DISCUSSION}

The circulating fleet is one of the most important data in estimating and evaluating pollutant emissions by road vehicles. It is based on the analysis of the composition of the circulating fleet that we obtain the perspective not only of the total pollutant emissions, but also of the relative contributions of each category of vehicles, favoring the performance of evaluations of specific scenarios in a more appropriate way.

Thus, the results obtained bring automobiles, motorcycles, and light commercial vehicles with a greater relative participation in the composition of the circulating fleet of RMS, and these vehicles have more advanced embedded technology and as a result, with lower emissions of pollutants. At the same time, in this circulating fleet, there are vehicles with high levels of intensity of use, causing an increase in the level of aging of the fleet and with inadequate maintenance generating higher levels of emissions, when compared to trucks and buses with more current technologies.

Besides, in an expressive and growing way, we see that automobiles represent the largest category of vehicles in circulation, as shown in Fig. 3.

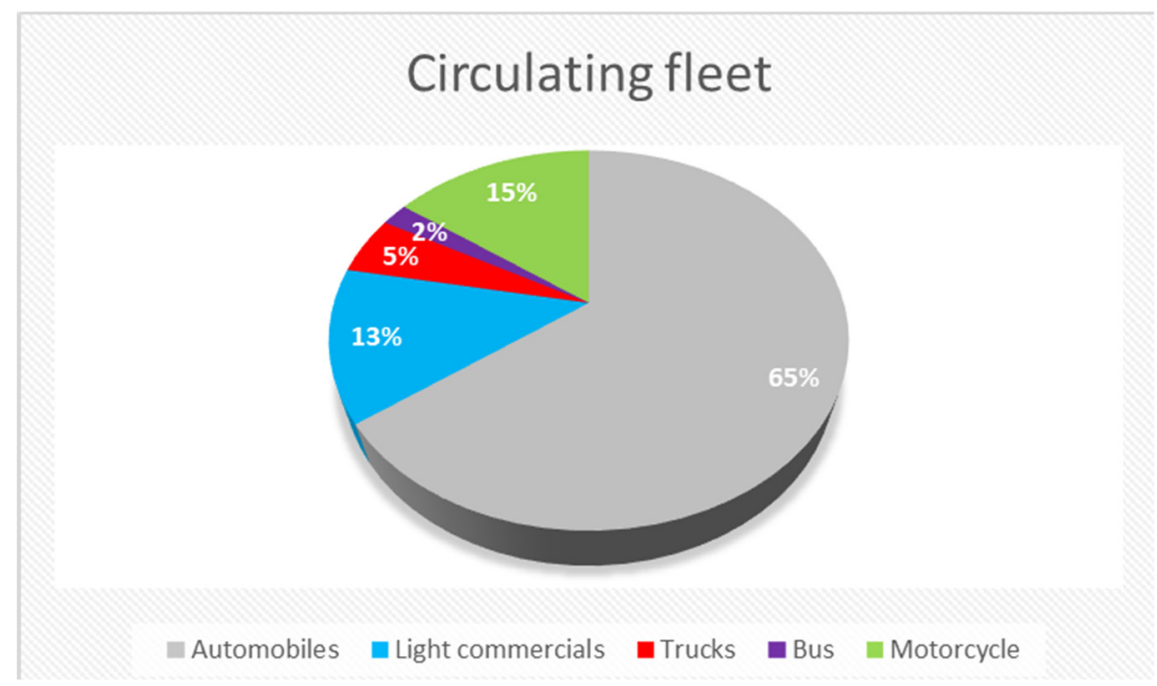

Figure 3: Relative composition of the circulating fleet. 
Fig. 3 shows the participation of each category of vehicles in the circulating fleet of RMS, and we see that buses have the lowest participation followed by trucks. Motorcycles represent $15 \%$ of the total circulating fleet, while light commercial vehicles account for $13 \%$.

However, in Fig. 4 we see that the total emissions of nitrogen oxides $\left(\mathrm{NO}_{\mathrm{x}}\right)$ come from trucks representing $58 \%$ of emissions, despite representing $5.28 \%$ of the circulating fleet.

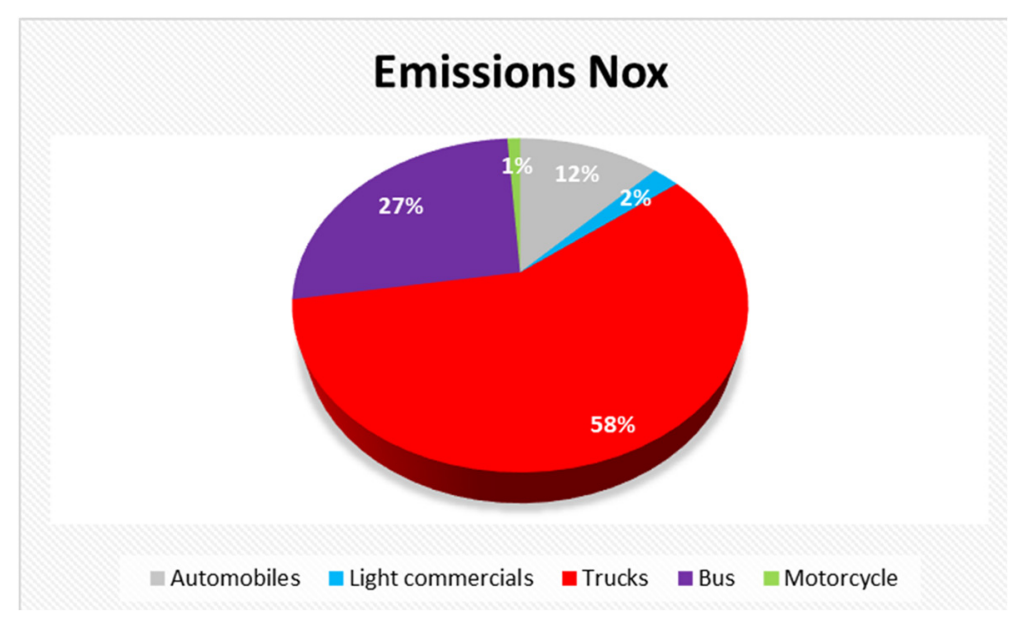

Figure 4: Relative contributions of vehicle categories to $\mathrm{NO}_{\mathrm{x}}$ emissions.

Although automobiles represent the largest category of road vehicles (65\%), they contribute about $12 \%$ of $\mathrm{NO}_{\mathrm{x}}$ emissions while buses contribute $27 \%$ of these emissions representing the smallest category of road vehicles with about $2 \%$.

The total emissions of particulate matter (PM) through the exhaust system are shown in Fig. 5.

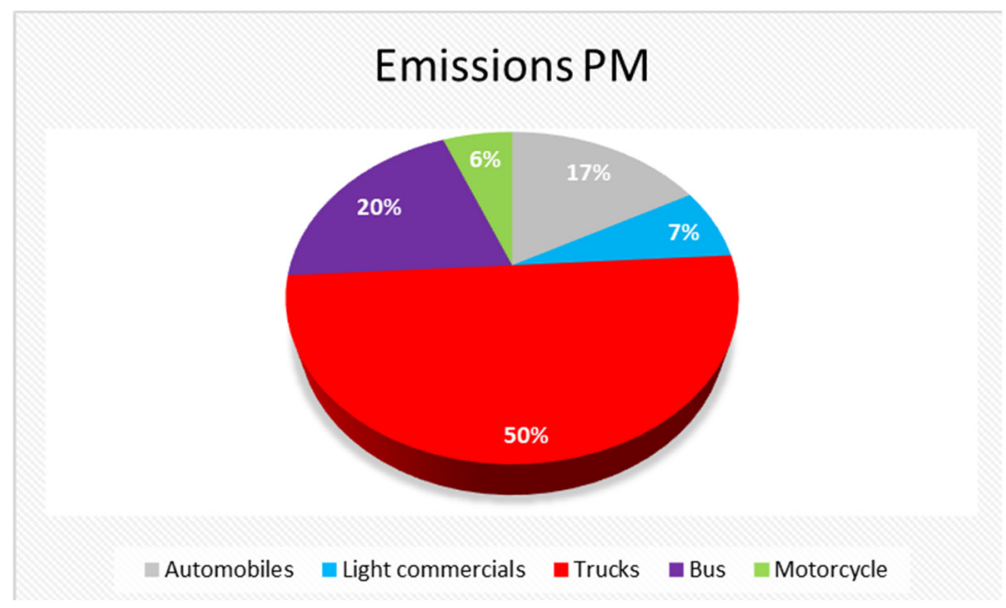

Figure 5: Relative contributions of vehicle categories to PM emissions. 
Fig. 5 demonstrates that even though buses and trucks represent the smallest participation in the circulating fleet, they emit the highest rates of PM in relation to the other categories, such as, for example, the category of automobiles.

However, the results obtained are relevant and similar to the results found for other metropolitan regions, this is because it occurs how to obtain from automobiles, motorcycles and light commercial vehicles despite having a greater participation in the circulating fleet, they had less information about the pollutants obtained because these vehicles an embedded technology is more advanced, fuel is cleaner even taking into account fleet aging and inadequate maintenance when compared to trucks and buses.

\section{CONCLUSION}

The main objective of this work was to investigate and analyze the contributions to air pollution in the RMS, generating more current information to promote continuous updates in this sense. For this purpose, the methodology proposed and developed by the Ministry of the Environment (MMA) and the Environmental Company was used from the State of São Paulo (CETESB), which quantifies emissions from vehicles powered by fossil fuels, from the Otto cycle and the diesel cycle, excluding electric and hybrid vehicles.

Based on this approach, it was estimated that RMS owns $36.48 \%$ of the circulating fleet in the State of Bahia, comprising approximately $65 \%$ automobiles and $7.0 \%$ heavy vehicles (trucks and buses). And even though heavy vehicles emit the highest levels of $\mathrm{NO}_{\mathrm{x}}$ and $\mathrm{PM}$, contributing approximately $84 \%$ and $70 \%$, respectively, of the pollution of these substances that contaminate the environment and affect human health. These results are pertinent and represent the contributions of motor vehicles to atmospheric pollution in large urban centers.

Thus, it is evident that the emission inventories are fundamental tools for the development of studies aimed at the analysis of air quality, as well as, in photochemical modeling. Although, there are still many uncertainties associated with its elaboration, such as, for example, the calculation of emissions, the characteristics of the fuels used, the circulating fleet of each region, as well as the technology on board.

For future work, it is suggested to draw up inventories covering other sources with a polluting potential to also know their contribution. And the study of these sources in models of air quality promoting a more realistic scenario of local air quality.

\section{ACKNOWLEDGEMENTS}

We are grateful to the Bahia Research Support Foundation (FAPESB) and to the HPC of the Centro Universitário SENAI CIMATEC.

\section{REFERENCES}

[1] Nueve de cada diez personas de todo el mundo respiran aire contaminado, 2018. Organización mundial de la salud (OMS), avenue appia 20, 1211 ginebra 27, suiza. https://www.who.int/es/news/item/. Accessed on: 26 Apr. 2021.

[2] Instituto Brasileiro de Geografia e Estatistica (IBGE), Banco de Dados - Cidades, 2018 (in Portuguese). http://www.cidades.ibge.gov.br/v3/cidades/home-cidades. Accessed: 20 Jan. 2019.

[3] Lyra, D.G.P.d., Modelo integrado de gestão da qualidade do ar da região metropolitana de Salvador/Diógenes Ganghis Pimentel de Lyra. - Campinas, SP: 2008 (in Portuguese).

[4] De Aguiar Filho, A.M. \& de Albuquerque, É.L., Inventário de Emissões Veiculares na Região Metropolitana de Salvador para o ano de 2010, 2012 (in Portuguese). 
[5] Loureiro, L.N., Panorâmica Sobre Emissões Atmosféricas Estudo De Caso: Avaliação Do Inventário Emissões Atmosféricas da Região Metropolitana Do Rio De Janeiro Para Fontes Móveis. Tese Universidade federal do Rio de Janeiro, 2005 (in Portuguese).

[6] De Almeida Albuquerque, T.T. et al., WRF-Smoke-CMAQ modeling system for air quality evaluation in São Paulo megacity with a 2008 experimental campaign data. Environ Sci Pollut Res, 25, pp. 36555-36569, 2018.

DOI: $10.1007 / \mathrm{s} 11356-018-3583-9$.

[7] Loriato, A.G., et al., High resolution emissions inventory using WRF-SMOKECMAQ integrated modeling for Great Vitoria region. Revista Brasileira de Meteorologia, 33(3), pp. 521-536, 2018.

[8] Araujo, I.B.d., Quantificação, Espacialização e especiação de emissões atmosféricas de origem veicular na Região Metropolitana da Grande Vitória/Igor Baptista de Araújo. - Vitoria, ES: 2016, 2005 (in Portuguese).

[9] Kitagawa, Y.K.L., Nascimento, E.G.S., Guarieiro, L.L.N., Albuquerque, T.T.D.A. \& Moreira, D.M., Assessment of primary air pollutants in a tropical metropolitan region by combining local and global emissions inventories. WIT Transactions on Ecology and the Environment, vol. 236, WIT Press: Southampton and Boston, pp. 99-110, 2019.

[10] Santos, F.S.d., Diagnóstico das emissões atmosféricas em Minas Gerais: Um estudo para fontes fixas e veiculares. Escola de Engenharia/Dissertação de mestrado. Belo Horizonte - Universidade Federal de Minas Gerais, 2018 (in Portuguese).

[11] BRASIL, Ministério do Meio Ambiente. Inventário Nacional de Emissões Atmosféricas por Veículos Automotores Rodoviários - Ano - Base: 2012. Relatório Final. Brasília: Ministério do Meio Ambiente. 114 p., 2013 (in Portuguese).

[12] CETESB, Qualidade do ar no estado de São Paulo 2013. Publicação CETESB. Série Relatórios/CETESB, ISSN 0103-4103, São Paulo, 2013.

[13] Mattos, J.A.B. \& Correia, E.L., Uma nova estimativa da frota de veículos automotives no brasil. Anais do VII Congresso Brasileiro de Energia, p. 1267, 1996.

[14] Schmitt, F.W., Metodologia de Avaliação de Eficiência Energética em Veículos Leves e Seus Impactos em Termos de Uso de Combustíveis/William Frederic Schmitt. - Rio de Janeiro: UFRJ/COPPE, 2010.

[15] Agência Nacional do Petróleo, Gás natural e Biocombustíveis. Anuário Estatístico Brasileiro do Petróleo, Gás Natural e Biocombustíveis (ANP), 2016 (in Portuguese). http://www.anp.gov.br. Rio de Janeiro: ANP. 265 p. Accessed 20 Jun. 2019.

[16] U.S. Environmental Protection Agency, Compilation of air pollutant emission factor, volume I: stationary point and area sources, AP42, fifth edition. Chapter 13: Miscellaneous Sources. 13.2.1 Paved Roads, Research Triangle Park, NC, 2011. https://www3.epa.gov/ttn/cheif/ap42/ch13/final/c13/s0201.pdf. Accessed 20 Jun. 2019.

[17] Ntziachristos, L. \& Boulter, P., Road transport: automobile tyre and brake wear and road abrasion. EMEP/EEA Air Pollutant Emission Inventory Guidebook 2016: Technical Guidance to Prepare National Emission Inventories, Publications Office of the European Union: Luxembourg, pp. 1-32, 2016. 